\title{
GEOCHEMICAL EXPLORATION FOR HEAVY METALS IN THE STREAM SEDIMENTS OF OKEMESI-IJERO AREA, SOUTHWESTERN NIGERIA.
}

\author{
Olusiji Samuel Ayodele ${ }^{1 *}$ \\ ${ }^{*}$ Department of Geology and Applied Geophysics, Ekiti State University, P.M.B 5363, Ado Ekiti \\ Email: samuelayodeleolusiji@yahoo.com,riksam2002@gmail.com
}

*Corresponding Author: -

Email: samuelayodeleolusiji@yahoo.com,riksam2002@gmail.com

\begin{abstract}
: -
The bedrocks and gold mineralization have been widely studied especially, in the southern extension of the Ilesha schist belt, but information regarding stream sediments in the area is rarely available in literature. The present study therefore, focused on stream sediments geochemical survey of Okemesi/Ijero axis within the northern extension of Ilesha schist belt using an integrated approach to elucidate the heavy metals potentials and its possible controlling environmental geological conditions. Detailed geological survey involved lithological and structural assessment of the bedrocks. Thirtyfive (35) stream sediment samples were collected at a depth of 20-25cm. Major oxides of the stream sediments for major elements were determined using atomic emission spectroscopy (AES). Trace and rare earth elemental analysis was done using inductively coupled plasma mass spectrometry (ICP-MS). Data evaluation was carried out using statistical packages for software simulation. Results showed that bedrock types are quartzbiotite-schists, banded-gneiss, granitegneiss, biotite-gneiss, calc-gneiss, porphyritic granites, charnockites, massive and schistose quartzites, mica-schists. Structural assessment of the bedrocks revealed folds, fractures and veins as products of Precambrian deformations. Sediments have relatively high concentration of heavy metals such as Mn (387-200ppm), Zn(76.518.52ppm), Pb(39.8120.23ppm), La 36.2-15.5ppm), Cu(12.68-13.65ppm). However, the folds, fractures and veins provided the groundwork for epigenetic type of mineralization in the studied area.
\end{abstract}

Keywords: Sediment; Bedrock; Heavy metals: Mineralization; Structures; Geochemistry

\section{(c) $(\$)$}




\section{INTRODUCTION}

Stream sediments originate from near surface of exposed rocks of igneous, sedimentary and volcanic regions. Some of these are easily eroded whereas; others such as the crystalline and metamorphic rocks are affected by streams only when altered in surface layers. Most streams in southwestern Nigeria are located on the basement complex which is within the reactivated part of the Pan African mobile belt between the West African and Congo cratons (Kennedy, 1965; Clifford, 1970). Geological field mapping is a reliable means of gathering useful information on the field where rocks can be observed and studied in-situ. Information gathered from such field work is presented on geological maps; it involves the use of topographical maps which serves as base maps upon which all geological observation are represented before the production of the solid drift maps. Geological structures are diagnostic features that are clues in determining the deformation history of rocks. Such structures include joints, faults, fractures, dykes and veins. These structures are developed by deep seated forces on and within the earth crust. Not all structures are deformational in nature, because they could have formed simultaneously with the emplacement of the host rocks or arose due to mountain building processes. Most tectonic forces ravaging the earth may be pre-tectonic or post-tectonic depending on the type of orogeny and its geological implications over a period of time. Jacobson and Webb 1946) were among the first to work on heavy minerals in the sediments of Nigeria, especially in wamba area (central Nigeria) in a 400km NE-SW trending belt. Other workers like (Matheis 1987) conducted the geochemical exploration for heavy minerals particularly $S_{n}-N_{o}-T_{a}$ in the southwestern part of Nigeria. While, Matheis and Caen - Vachette (1983) studied the pegmatities of Pan - African reactivation zone covering areas of Egbe, Ijero and wamba, and also distinguished mainly between the barren and mineralized pegmatites. (Matheis 1987) also worked on the geochemical exploration guides for rare metals with a case study of Ijero. (Allen 1965) however, noted the characteristic heavy minerals of the Niger and Benue river basins in his study of the mineral suite of the Niger delta. (Nedeco 1961) recorded the heavy minerals of parts of the eastern Niger delta. (Mecleod 1954) reported high concentrations of columbite in the Jos - Bukuru younger granite complex and showed close correlation between primary and alluvial deposits. Awosika et al.,1982 conducted a research on the heavy minerals in the Nigerian river sediments and concluded that the textural properties of terrigenous sediments are almost entirely controlled by transportation and deposition environment while its mineralogical composition is a function of provenance. The occurrence and abundance of heavy minerals suits are influenced by various factors such as specific gravity and hardness of individual minerals. Some minerals such magnetite, tourmaline, Zircon, rutile and sphene can form authigenically in sediments. Also, from the record of previous workers, we are able to understand that stream sediments contain a wide range of minerals, clay minerals and also organic matter. Geochemical dispersion of gold in stream sediments in Paleoproterozoic Nyong series, southern Cameroon was also undertaken by Mubfu et al.,(2014) in an attempt to explore for gold using stream sediments collected in the

Ngo Vayang area of southern Cameroon, and revealed that the Au-Hf element association from the R-mode factor analysis indicated gold mineralization while $\mathrm{U}-\mathrm{Th}-\mathrm{Pb}-\mathrm{W}, \mathrm{Nb}-\mathrm{Ta}-\mathrm{Co}-\mathrm{V}$, AuHf-Cu associations reflected lithologic controls. Akintola et al.,(2013) carried out the petrography and stream sediment geochemistry of Ede and its environs in order to identify the rock units with their mineralogical appraisal and to determine the concentration and distribution of major and trace elements in the stream sediments with a view to elucidate the mineral potentials of the study area.Statistitical evaluation of stream sediments in interpreting the river catchment of high grade metamorphic terrains was also carried out by Rupasinghe et al., (2009) and concluded that stream sediment geochemistry can aid in recognizing variations in upstream geology in several high grade metamorphic lithotectonic units having different metamorphic and tectonic histories including the Highland complex, Vijayan complex, Wanni complex and Keduganwa complex of Sri lanka However, this study tends to carry out geochemical exploration for heavy metals in the sediments of Okemesi-Ijero area, to determine the underlying lithologic units and to carryout systematic geochemical investigation of the stream sediments in order to discover the heavy metals present in them and to obtain a baseline geochemical information for the area.

\section{Location and Accessibility}

The study area lies within latitudes $7^{0} 45^{\prime} \mathrm{N}$ and $8^{\circ} 00^{\prime} \mathrm{N}$ and longitudes $4^{0} 52^{\prime} \mathrm{E}$ and $5^{0} 08^{\prime} \mathrm{E}$. It covers part of the topographic map sheet No. 243 (Ilesha N.E. 1:50,000) and sheet No. 244 (Ado N.W. 1:50,000). The study areas cover parts of Ekiti and Osun, southwestern Nigeria with a total surface area of $821.4 \mathrm{~km}^{2}$ (Fig.1). Major towns in the area include Okemesi and Ijero Ekiti. Other towns include Epe, Ikoro, Effon, Ipoti, odo-owa, Ayegunle, while those in Osun State are Oke-ila, Ilupeju, Edemode, Orangun and Oba-sinkin .The areas which fell within Osun, Southwestern Nigeria can be rated moderately motorable due to interconnectivity of roads, while areas within Ekiti can be rated poor because there are only minor roads and footpaths which are not motorable. Localities within Ekiti are mainly small villages with linear settlement along the road, while nucleated settlement predominates in Osun. The study area is generally accessible through network of all seasonal roads and motorable tracks which links it with other part of the country. Similarly, villages and towns have major and minor roads and also footpaths which are inter-linked to one another. 


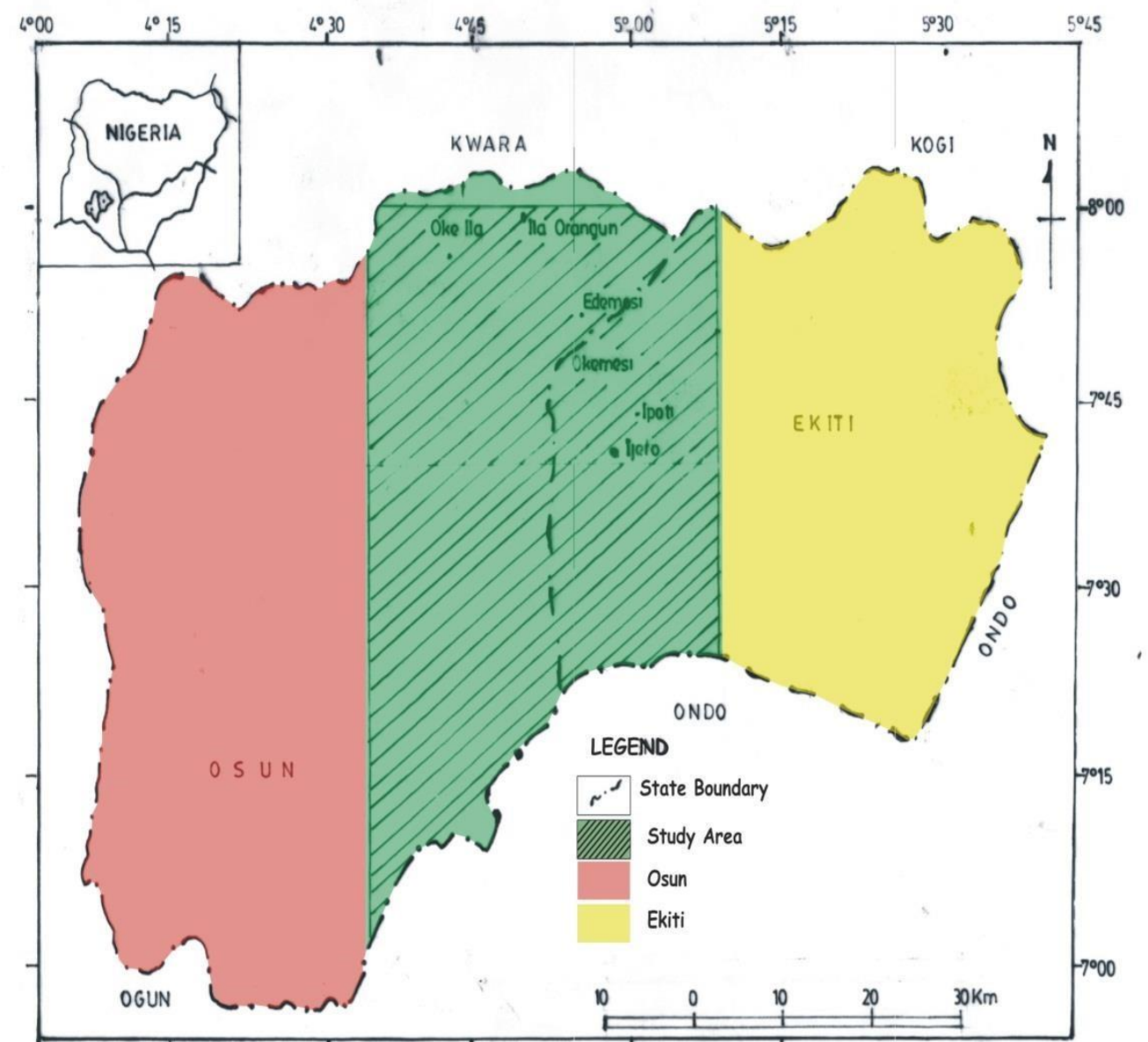

Fig.1: Map of Osun and Ekiti, southwestern Nigeria showing the study area (inset: Map of Nigeria showing Osun and Ekiti States).

\section{Drainage system of the study area}

The hills are separated by valleys and gullies, which accumulate water during the rainy season, flowing down stream to erode and expose the underlying rocks and carries weathered residues including minerals down the slope into streams and rivers. The streams spread out from a central point, forming dendritic drainage pattern as a result of its branching (Fig.2). They develop where the cover channels follow the slope of the terrain. Dendritic system forms in Vshaped valleys as a result of the rock types whether porous on non-porous, while the drainage pattern where the topography is dominated by series of ridges is the trellis type which suggests that the drainage is structurally controlled. Major rivers in the study area include river Osun found along Okemesi road, river Oyi, which flows in a southerly direction. A waterfall was encountered around Oke-Ila called Ayikunnugba waterfalls and river Isa etc. Most of the streams in the study area are actively flowing while some are stagnant and others have dried channels owing to dry season. The disposition of rivers and stream within the study area is controlled by the following factors namely; the gradient (slope) of the highland, the prevailing climatic conditions, the structural features such as joints, fractures, veins and foliations, geomorphology and physiology of the area and the lithology of the area (Akanni,1992).

\section{Geology of the Study Area}

The study area is underlain by crystalline rocks of Precambrian basement complex of southwestern Nigeria, which is also part of the basement complex rocks of Nigeria. The study area is also part of the regional Dahomeyide fold belt defined by Affaton et al. (1991). The dominant rock type in the study area is the quartzites of the Effon Psammite Formation which occurs mostly as massive quartzites, schistose quartzites and quartz schists. The Effon Psammite Formation which extends to Okemesi (Hubbard, 1966; De Swardt, 1953; Dempster, 1967) is a belt of quartzites, quartz schist and granulites which occurs largely east of Ilesha and runs for nearly $180 \mathrm{~km}$ in a general NNE-SSW direction. The various lithologic descriptions of the different rocks mapped in the study area are discussed below.

\section{Banded gneisses}

This lithology covers the southwestern part of the study area around Okokoro, Aba Francis and Aba-Ori-Apata near Ikoro Ekiti. Texturally, they are medium to coarse grained with alternating bands of light and dark coloured portions of about $3 \mathrm{~cm}$ thickness with complete gradation between them. They occur as low lying outcrops which have been intruded by pegmatite in the south eastern corner of the area. The rock consists of alternating felsic and mafic minerals and structures like banding, microfolds and fractures were noticed on the outcrop. They have whitish grey tones. The samples mapped 
around Okemesi and Ipoti are medium to coarse grained and are foliated and display compositional banding of the mafic and felsic minerals. The rock strikes at $333^{\circ}$ and dips at $60^{\circ} \mathrm{W}$.The mineralogy consist of quartz, biotite and orthoclase and microcline feldspars.

\section{Quartzites}

These tend to form good topographical features which rise up to about 400metres above the surrounding terrains forming ridges. Quartzites cover the northern part around Oke-Ila, Ilupeju areas to central, western (Ayegunle), extending to the southwestern and southern parts of Okemesi (Ajindo) of the study area. Around the study area, the varieties of quartzite encountered are massive, milky, smoky, sugary, ferrugineous and schistose quartzites. However, schistose, ferrugineous and smoky varieties are the commonest in Okemesi area. The massive quartzites are not foliated but hard and are compact, the schistose quartzites are foliated and exhibit alternations of felsic mineral such as quartz and mafic mineral such as biotite with planar fabric. The milky ones have milky appearance by inspection and developed slickenside surfacesn with specks of muscovite. The smoky ones are formed by different oxidation states of iron in the crystal lattices of the rock or due to impregnations of some transition elements during the rock formation. The sugary ones have granular textures and are friable when struck with hammer.The ferruginous types are rich in iron. They are very common in Okemesi and itawure.The quartzites have varying textures from equigranular, medium grained to coarse grained. The varieties of quartzites are closely related that, often, it is impossible to indicate them as separate units on the map. The quartzites consist of mainly quartz which is usually more than $70 \%$ with minor amounts of interlocking grains of biotite and orthoclase. Structurally, the quartzites are jointed, with some having joint sets around Ayikunnugba (Oke-Ila) area, while others are foliated. Dips ranging between $40^{\circ} \mathrm{W}-66^{\circ} \mathrm{W}$ were measured around Soso and Oko Ajindo areas. In some areas for instance, they have very high dips ranging from $66^{\circ} \mathrm{E}$ to almost horizontal at Okemesi, most especially along the limbs and fold closure. The quartzites in the area have orange-yellow colour due to mineral impurities.Quartz vein is the dominant structural feature on the rocks in this locality.

\section{Biotite-Gneisses}

This is a foliated, medium to coarse-grained, dark to almost black coloured rock composed chiefly of biotite and little quartz. It occupies the north central area and extends towards the north western part of the study area. A band of biotite gneiss concordantly lies within the quartzites around Ajindo area. The rock has been severely weathered and covered with sand thereby making field observation difficult to carry out. The varieties seen at Ikoro and Ijero are the highly foliated type with bands of black tints imposed by biotite impregnations alongside felsic minerals such as quartz and plagioclase feldspar. Most of the mineral alignments are conformable with the foliation planes of the adjacent schistose rock.

\section{Granite-gneiss.}

The granite gneisses are common in Okemesi and Epe. They exhibit mineralogical banding of felsic and mafic minerals. The felsic minerals are the quartz and feldspar (plagioclase) and mafic minerals are biotite. The texture is medium to coarse grained.

\section{Biotite -Schists}

The biotite schists encountered in the study area occurs around Arapate Erigbe and Soso area of EkitiState as a lenticular body within the quartzites and migmatite gneiss, and it is exposed due to stream activity as low lying outcrop. It has undergone various levels of deformation. Structurally, foliation is present thereby making the name "biotite schist" appended to the rock as confirmed by petrographic studies. Other structural features on the rock include microfolds and joints which control the stream flow. Field observations showed that this rock dips at $48^{0} \mathrm{~W}$ to the surrounding rocks. The rock is medium grained and contains quartz and biotite which is the dominant mineral, and it is dark grey in colour. The rock also occurs in Ikoro and Ijero area as a schistose rock with grayish colour, and with black patches of biotite, It exhibits fine grained texture. It covers nearly two-thirds of Ijero area with pegmatite intrusions along Ijero-Ikoro road. It is also found in Arapate/Soso area with structures such as foliations and micofolds. Mineralogically, it contains quartz and biotite.

\section{Quartz-Biotite Schists}

This group of rock occurs in lowland areas between quartzite and banded gneiss around Oko-Esinkin2 area (eastern part of Okemesi) where it has been exposed by stream channel and road cut. The rock has been highly deformed with the adjacent migmatite-gneiss- quartzite complex, the foliations on the outcrop is defined by biotite streaks. The rock has medium to coarse grained texture and consist mainly of biotite, quartz, plagioclase feldspar and orthoclase feldspar. Structures found on the outcrop are fractures, and the rock is grey to dark in colour.

\section{Pegmatites}

This lithologic unit ranges from a few meters in length and is located in the southeastern part of Okemesi where it intrudes the banded gneiss around Aba Francis and Ikoro area as an isolated hill. Texturally, it is extremely coarse-grained with quartz, feldspar and muscovite as distinguished mineral component. Quartz vein, joints and veinlets are the structures observed on the outcrop. Based on field observation, the pegmatite is the complex type with distinct textural and mineralogical variations with an impure white colouration. It is the youngest rock in Ikoro area, unlike the Okemesi pegmatite which is the simple type due to uniform variation of its constituent minerals. Pegmatite intrusions also occur towards the south-western part very close to the centre of Ijero town, which is also complex. It extended to the quarry site 
in Ijero along Ijero- Ipoti road. The pegmatite in Ijero area is zoned, consisting of massive quartz at the core, and followed by mica schists with smoky quartz impregnated with tourmaline and purplish quartzite. In Ara and Epe area of Ijero, the pegmatites here intruded into the biotite schist and migmatite gneiss that occupies the central part of the area, covering about three-quarter of the total land mass. The pegmatites in this area are very coarse grained igneous type with phenocrysts over $250 \mathrm{~mm}$ in length, usually of granitic composition. The pegmatite in Ipoti and Odo Owa areas are associated with cassiterite-tantalite mineralization (Fadipe, 1988). They are found associated with migmatite gneiss and amphibolites with very coarse grained texture and consists of feldspar, tourmaline and garnet while pegmatites in Ijero is enriched with unusual trace elements which thus result in the crystallization of unsual rare minerals such as beryl, tourmaline, columbite and tantalite. The pegmatites in Ijero occur as a low but large elongate hill of average height of about 50m above sea level. Some of the pegmatites in Ijero have been and are still being worked on most especially at Ijero and other villages such as Ikoro, Odo-Owa, Saloro and Oke Asa.

\section{Calc-gneiss}

This is a typical gneissic rock with abundance of calcium. It exhibits a characteristic black colour with white fragments of quartz. The texture of the rock is mostly fine grained. Joints are the major structures discovered on the outcrop, and are common in most parts of

Ikoro. Part of the lithological unit is exposed at Odo agba (Ikoro) where the stream takes it course. They are medium to coarse grained.It is also common in Ijero where it is composed chiefly of calcite and quartz. It occurs mainly as nodules and discontinuous streaks up to four inches in thickness. It is also made up of a mosaic of twinned grains of calcite enclosing isolated rounded crystals or composite spots of silicate minerals.

\section{Granites}

Varieties of granites based on mineral composition, texture and grain sizes are very prominent in the south eastern part of the study area most especially in Ofale, Osun/ Epe, Iroko, and Idao parts of the study area and form well defined boundaries with the quartzites. Their textures range from fine, medium to coarse grained. They occur as hilly, low lying, flat and extensive outcrops in most area with sparse vegetations. Structures common the outcrops include quartz vein, veinlets, pegmatite dykes which trend north-south, exfoliation, folds of different styles, xenoliths etc. A typical granitic rock must have $>60 \%$ of quartz to be termed an acid igneous rock. However, the granites occur as pockets of rocks within the biotite gneiss in Ikoro and Ijero area. They have colour variations ranging from specks of whitish, grayish to ash colour and patches of dark colour indicating ferromagnesian minerals.

\section{Mica schists}

The mica schists extend across most part of Ipoti, Odo Owa and Ijero, but occur prominently around Ipoti and Ijero. They are highly susceptible to weathering and erosion thereby reducing the quantity of fresh samples. In these areas, quartzmuscovite and quartzmuscovite-biotite schist are exposed in many places and have been highly pegmatized. The quartz biotite schist found in the area could be due to boron metasomatism traceable to tourmaline at Odo Owa where they are relatively well exposed.

\section{Migmatite-gneiss complex}

This is presumably the oldest group of rocks and the most wide spread of all the lithologies, occupying $30 \%$ of the total surface area of Ijero and its surroundings. Its concordant lithostratigraphic relationship with the juxtaposed quartzite at Ayegunle gives credence to its probable metasedimentary origin. It is a mixed rock with a characteristic nature of a typical metamorphic rock which has taken an igneous character through partial melting. The migmatite has a mineralogical composition of quartz, orthoclase feldspar, hornblende and mica.. It is not widely distributed in Ara Epe area unlike the pegmatites, but occupies the northern part. It is characterized mostly by alternating light and dark bands of minerals. In Ipoti, Odo Owa area, the rock has been weathered in-situ to give rise to high quality clays of economic importance, whereas, it occurred as a fresh low-lying outcrop in Ijero. It also possesses schlieren texture which is an example of granite formation in migmatites. This is typical of the samples picked from Epe. Migmatites in Epe are characterized by ptygmatic folds and are believed to exhibit ductile deformation of the gneissic banding. Structures like folds and microfaults were also seen on the outcrop. The strike value of the rock is $340^{\circ}$ and $\operatorname{dip}$ is $32^{\circ} \mathrm{W}$.

\section{Charnockites}

The charnockites occur as an intrusive body north of Odo Owa within the massive quartzites and the gneisses as a coarsegrained variety of charnockites which are foliated. They vary in texture and petrography and range from banded types to fine and medium grained. Though, the coarse-grained varieties are common around Ipoti and Odo owa area. They also occur as discrete and individual bodies within the migmatite-gneiss-quartzite complex. Mineralogically, it consists of hornblende, biotite with little or no quartz. Structures seen on the rock are solution holes, quartz veins. The various rock units mapped in the course of field work were compiled to produce a geologic and cross-section map of the study area (Fig.3).

\section{Method of study}

The methods adopted for this research work is divided into two aspects namely field and laboratory operations. The field operation is essentially geologic mapping of the study area to determine the underlying bedrock units. Thirty-five (35) 
stream sediment samples were obtained. Sediment samples were taken at a depth of 20-25cm (Fig.4); they were bagged and labeled to avoid mix up before transportation to the laboratory. The geographical locations of each sample collected were noted and recorded in the field notebook. Also the characteristic features of the stream sediments collected were also recorded in the field notebook. The laboratory operations involve pulverization and homogenizing the stream sediment samples using a pulverizer to allow to crush the coarse particles in the sediments after which the milling machine was used for further pulverization until the samples became very fine in size $(-15 \mu \mathrm{m})$. $40 \mathrm{~g}$ of the homogenized sample was analyzed by inductively coupled plasma mass spectrometry (ICP-MS). Samples were dissolved using Lithium Tetraborate fusion method followed by $\mathrm{HCl}$ and $\mathrm{HF}$ acid digestion (Watts and Johnson, 2012). This digestion method was chosen to provide a more aggressive dissolution of refractory minerals than a standard mixed-acid method. The sediment samples were placed in a sample container which was properly labeled. The digested samples from both areas were transferred to ACME Laboratories, East Vancouver, Canada.

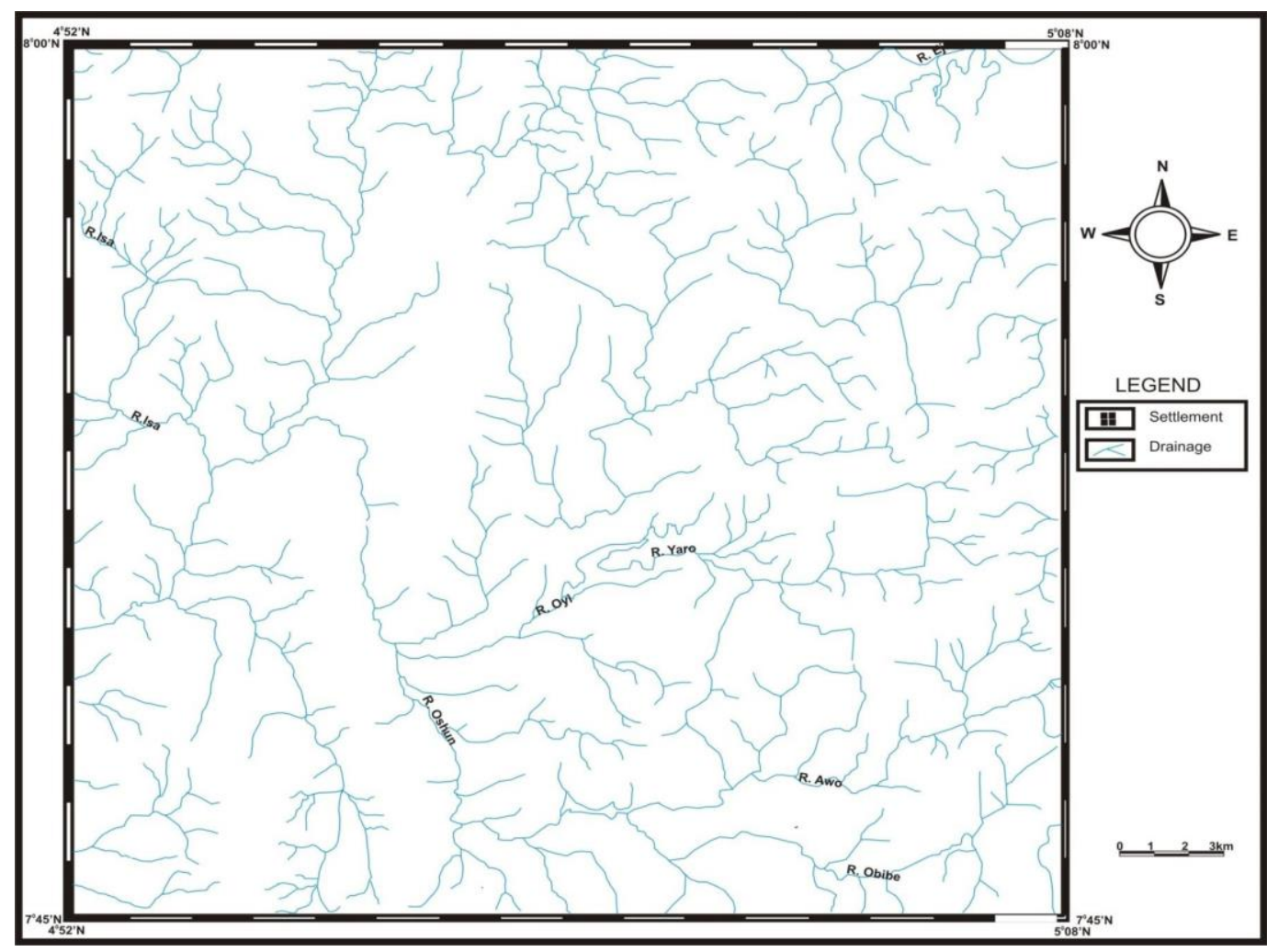

Fig. 2: Drainage map of the study area 


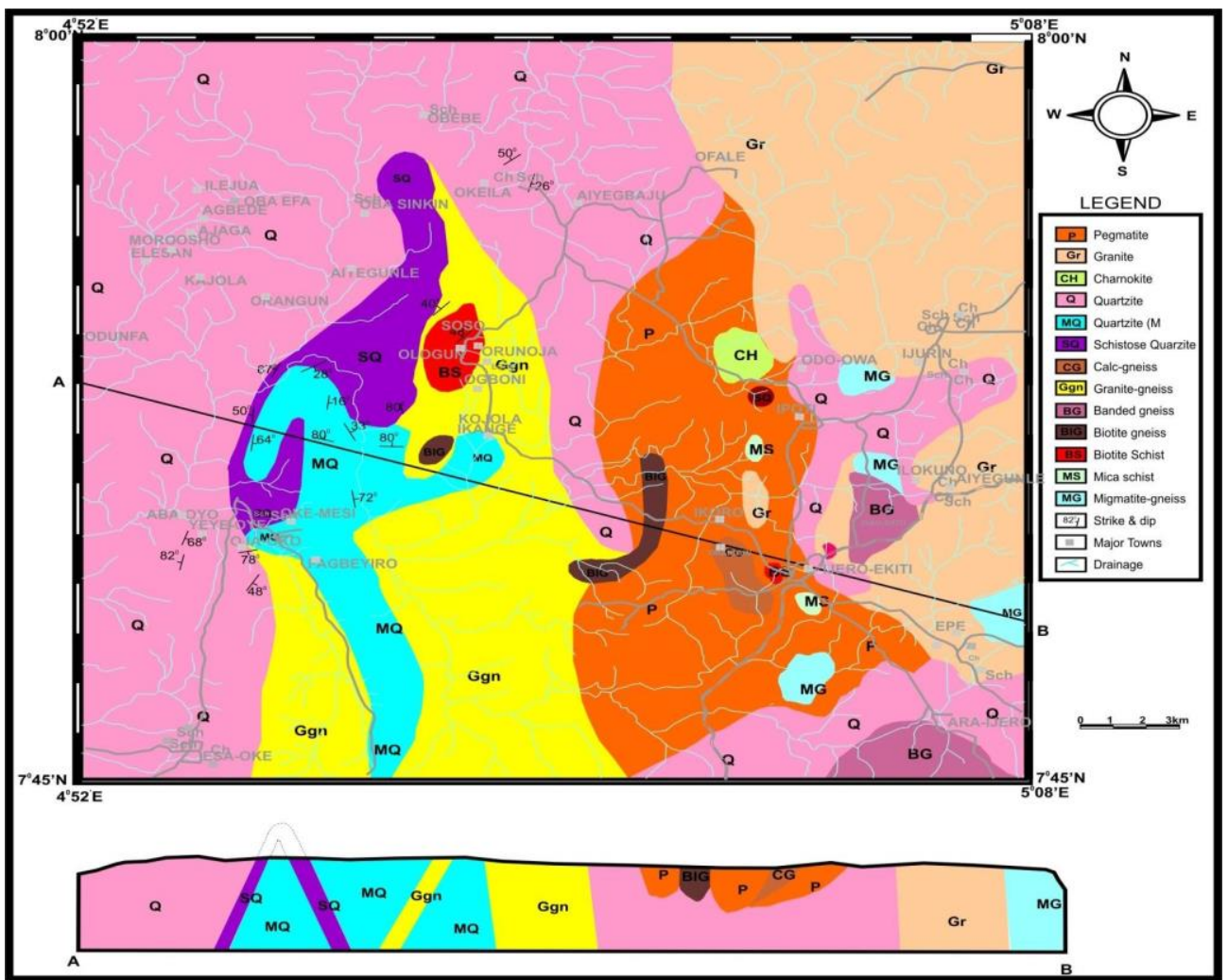

Fig. 3: Geological map of the study area (After Ayodele, 2015)

\section{Results and Discussion Geological Mapping}

The field description and characteristics of the various rock units mapped in the studied area has been compiled to produce a geological map of the studied area. (Fig.3). The geological map revealed the dispositions of the various rock units in the area. Also, from the geological map, migmatites are the oldest rocks in the study area, a few lithologies such as the pegmatites, mica schists, charnockites and granites occur as intrusive bodies within the migmatite-gneiss, and others such as granite-gneiss, calc-gneiss etc form discrete, disseminated and linear bodies within the massive quartzites and the schistose types. The strike values of the quartzites (schistose and massive) range from $024^{0}-046^{\circ}$ in some places. Also, the rocks dip in the western direction, with values such as $40^{\circ} \mathrm{W}-80^{\circ} \mathrm{W}$ in some areas of study, while other areas also dip in the eastern direction with dips such as $72^{\circ} \mathrm{E}-80^{\circ} \mathrm{E}$ respectively. The high dip values could be attributed to several episodes of deformation that characterize the rocks in the area which is manifested in the brittle nature of the quartzites that display several joints and fracture sets which also control the drainage pattern in the area. Also, the existences of structures in the area are also justified as seen on the cross-section map which confirmed the presence of folding on the rocks especially on the schistose quartzites. The type of fold here is an antiform.

\section{Major Oxides in Stream sediments}

The major oxide composition of the stream sediments is presented in Table 1. From the results $\mathrm{MgO}, \mathrm{Na}_{2} \mathrm{O}, \mathrm{P}_{2} \mathrm{O}_{5}$ has low concentration similar to the chemical composition of the rocks which is between 0.0054-0.003\%, $\mathrm{Fe}_{2} \mathrm{O}_{3}$ value ranges between $16.643 \%-1.306 \%$. The concentration is high in Odo-OwaAbidogun River and low in Esa Oke 2. The concentration of $\mathrm{Fe}$ in these sediments could be attributed to intense weathering, transportation and deposition of alumino silicate bearing minerals such as micas, feldspars, biotite into the stream bed or the leaching of iron from iron- bearing rocks such as ferruginous quartzites and granites. However, the result also revealed that $\mathrm{MnO}$ concentration is high in the stream sediments just like in the rocks. It revealed an economic concentration in all the samples collected. The concentrations are manifested in Baba Iyabo, EsaOke 17, Ijero-Ipoti River, Kajola 16, and Ofale road sediments respectively. Weathering of rocks in the neighborhood of streams usually serves as sources of mineral enrichment in sediments. 
Table 1: Major Oxides in Stream sediments (\%)

\begin{tabular}{|c|c|c|c|c|c|c|c|c|}
\hline Samples ID & $\mathrm{Fe}_{2} \mathrm{O}_{3}$ & $\mathrm{MnO}$ & MgO & $\mathrm{CaO}$ & $\mathrm{Na}_{2} \mathrm{O}$ & $\mathbf{K}_{2} \mathbf{O}$ & P2O5 & $\mathrm{TiO}_{2}$ \\
\hline Agbagbara & 5.315 & 587.405 & 0.066 & 0.252 & 0.062 & 0.289 & 0.044 & 2.864 \\
\hline baba Iyabo & 5.664 & 1354.259 & 0.265 & 0.238 & 0.101 & 0.759 & 0.037 & 3.066 \\
\hline Baba Orioke $8 \mathrm{~b}$ & 2.869 & 407.956 & 0.199 & 0.350 & 1.004 & 5.085 & 0.048 & 1.049 \\
\hline Baba Orioke 8c & 2.519 & 304.676 & 0.398 & 0.700 & 2.049 & 4.627 & 0.050 & 0.777 \\
\hline Ede 1 & 6.823 & 677.775 & 0.812 & 0.266 & 0.670 & 4.157 & 0.092 & 1.163 \\
\hline Ede 2 & 10.611 & 1606.004 & 0.298 & 0.308 & 0.522 & 3.037 & 0.406 & 1.381 \\
\hline Effon 1 & 4.101 & 120.063 & 0.050 & 0.070 & 0.034 & 0.181 & 0.055 & 0.404 \\
\hline Effon Okemesi 3C & 1.398 & 156.211 & 0.050 & 0.028 & 0.023 & 0.181 & 0.018 & 0.706 \\
\hline Effon Okemesi & 2.354 & 419.575 & 0.000 & 0.042 & 0.105 & 0.458 & 0.048 & 1.523 \\
\hline Effon Okemesi 2 & 4.542 & 601.606 & 0.000 & 0.000 & 0.036 & 0.193 & 0.030 & 2.067 \\
\hline Esa Oke 2 & 1.306 & 94.243 & 0.050 & 0.028 & 0.028 & 0.386 & 0.027 & 0.550 \\
\hline Esa Oke 3 & 1.637 & 170.412 & 0.000 & 0.042 & 0.038 & 0.096 & 0.041 & 0.460 \\
\hline Esa Oke 6 & 7.393 & 387.300 & 0.116 & 0.140 & 0.253 & 1.615 & 0.096 & 1.301 \\
\hline Esa Oke 14 & 4.009 & 886.917 & 0.216 & 0.168 & 0.108 & 0.759 & 0.030 & 2.185 \\
\hline Esa Oke 17 & 8.882 & 2053.981 & 0.149 & 0.238 & 0.286 & 1.398 & 0.096 & 5.107 \\
\hline Ido - Ile 2 & 1.968 & 214.306 & 0.050 & 0.084 & 0.042 & 0.193 & 0.034 & 0.639 \\
\hline Ikoro - Okemesi & 4.506 & 943.721 & 0.298 & 0.462 & 0.526 & 3.145 & 0.087 & 1.648 \\
\hline Ijero - Ipoti River & 2.538 & 1447.211 & 0.116 & 0.224 & 5.596 & 1.012 & 0.190 & 0.600 \\
\hline Ilokun 1 & 3.310 & 331.787 & 0.249 & 0.518 & 0.690 & 3.699 & 0.064 & 0.766 \\
\hline Iroko 16 & 3.292 & 317.586 & 0.415 & 0.546 & 0.786 & 1.747 & 0.034 & 0.544 \\
\hline Kajola 16 & 4.156 & 1059.911 & 0.182 & 0.168 & 0.069 & 0.627 & 0.011 & 1.515 \\
\hline Odo Owa Abidogun & 10.850 & 872.716 & 0.862 & 0.126 & 0.124 & 2.049 & 0.117 & 1.084 \\
\hline Ofale Road & 16.643 & 1850.003 & 0.182 & 0.308 & 0.216 & 1.964 & 0.215 & 0.932 \\
\hline Okemesi 2 & 1.067 & 74.878 & 0.000 & 0.000 & 0.022 & 0.217 & 0.016 & 0.270 \\
\hline Okemesi 3 & 1.103 & 65.841 & 0.000 & 0.000 & 0.027 & 0.157 & 0.016 & 0.143 \\
\hline Okemesi 4 & 1.195 & 157.502 & 0.000 & 0.000 & 0.026 & 0.349 & 0.014 & 0.494 \\
\hline Okemesi 6 & 2.832 & 548.675 & 0.066 & 0.084 & 0.117 & 0.578 & 0.041 & 1.286 \\
\hline Okemesi 9 & 1.986 & 148.465 & 0.000 & 0.000 & 0.013 & 0.121 & 0.021 & 0.452 \\
\hline Omi Osa & 1.011 & 91.661 & 0.000 & 0.056 & 0.151 & 0.856 & 0.021 & 0.087 \\
\hline River Akola & 0.938 & 154.920 & 0.000 & 0.000 & 0.035 & 0.494 & 0.041 & 0.574 \\
\hline River Elewu & 1.508 & 311.131 & 0.033 & 0.196 & 0.807 & 3.025 & 0.062 & 1.079 \\
\hline River Eri & 5.168 & 1648.607 & 0.249 & 0.196 & 0.443 & 2.109 & 0.076 & 1.029 \\
\hline River Isa 7C & 1.287 & 201.396 & 0.033 & 0.126 & 0.481 & 4.651 & 0.044 & 0.107 \\
\hline River Oyi & 3.145 & 627.426 & 0.083 & 0.126 & 0.194 & 1.217 & 0.057 & 1.146 \\
\hline Oke - Ila 1 & 3.696 & 471.215 & 0.133 & 0.252 & 0.429 & 2.085 & 0.071 & 0.719 \\
\hline
\end{tabular}


Table 2: Trace elements in stream sediments

\begin{tabular}{|c|c|c|c|c|c|c|c|c|c|c|c|c|c|c|c|c|c|c|c|c|c|c|c|c|c|c|c|c|c|c|c|}
\hline$n \in$ & 140 & $\theta$ & 8 & $\pi$ & $i$ & 1 & 6 & in & 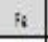 & is & 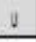 & $\lambda$ & in & 3 & 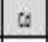 & 56 & 1 & $v$ & $n$ & ces & 34 & 86 & 16 & 0 & 3 & $z$ & 3 & 3 & $s$ & a & \\
\hline$t$ taris & OS & 12. & $15 \Omega$ & $3: 8$ & 0 & 9 & 6 & 459 & 19 & 06 & 4 & 0 & 165 & II & 0007 & 0.11 & $0 \mathbb{Z}$ & 16 & II & 00 & 0.11 & $0:$ & $\xi$ & 89 & $\approx$ & 619 & 11 & 0 & 11 & $75: 9$ & b. \\
\hline $\cos 1000$ & 0. & 186 & 111 & 368 & 40 & $13:$ & 116 & 106 & 30 & 08 & 18 & 0 & 15 & 11 & 000 & 0.14 & on & :8 & I & 00 & 0.14 & 02 & 3 & no & 113 & \$41 & 18 & 0 & 14 & 800 & 2. \\
\hline sis orksto & 09 & 112 & 73 & ut & 0 & $\because 5$ & ;) & 116 & 196 & 02 & 99 & 0 & 748 & E4 & 0007 & 0.11 & 03 & 4 & 454 & 00 & 0.11 & $0 x$ & $E$ & 4 & 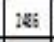 & 133 & 1 & 1 & 17 & $1: 1]$ & 1612 \\
\hline sis $00 k 686$ & 0. & $112 \pi$ & 785 & $u$ & 0 & 134 & 42 & 31 & 137 & 11 & 19 & 0 & 115 & 97. & 0068 & 0.12 & 0. & 4 & 67. & $0 \mathrm{EL}$ & 0.1. & $0 Z$ & $\varepsilon$ & 94 & 178 & 502 & 15 & 4 & I! & 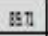 & 13:! \\
\hline$: 1$ & $0 x$ & 118 & $4: 8$ & 716 & 0 & 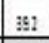 & 118 & 3 & $3 \pi$ & 16 & 61 & 0 & 245 & $\$ 9$ & 006 & 0,15 & $0 E$ & 46 & $\Xi$ & 0.8 & 0.17 & QE & 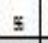 & $\pi$ & 68 & 543 & 41 & 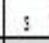 & 15.1 & 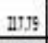 & 1284 \\
\hline : 82 & 14 & 118 & 398 & in & 35 & 201 & $34 \pi$ & 124 & $5 \pi$ & 45 & \& & 0 & 195 & \$1 & 0.12 & 018 & 03. & 58 & g1 & OI & 0.18 & 03. & 2 & 42 & 58T & M48 & 15 & 1 & 94 & $3: 58$ & 121 \\
\hline :tnd & $0 \pi$ & 1012 & 89 & 123 & 0 & 8 & 13 & 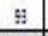 & 13 & 15 & 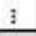 & 0 & 201 & 13 & 000 & 0.16 & 0.1 & 4 & I & 00 & 0.16 & 0.1 & 4 & 11 & I & 505 & 13 & 0 & 3t & ELS & $\$ 1$ \\
\hline atrolvas: & $0 x$ & 996 & 100 & 115 & II & $\$ 1$ & 18 & 111 & 0.16 & 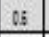 & 11 & 0 & 19 & II & i & 0.1 & 0.1 & 16 & II & 0 & 0.1 & 0.1 & 3 & 14 & I & 129 & or & 0 & 18 & $4 \pi$ & 115 \\
\hline itnolumal & on & 482 & 198 & 35 & 0 & 13 & 19 & 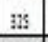 & 118 & 05 & 43 & 0 & 379 & II & 000 & 0.1 & 0.11 & 19 & I & 08 & 0.1 & OII & 2 & 14 & 1100 & 1158 & 11 & 0 & 07 & 36.13 & $\mathrm{~ns}$ \\
\hline thenown? & or & 119 & 155 & 111 & $n$ & 15 & 11 & 46 & $14 T$ & 19 & 38 & 0 & 137 & 8 & 006 & 0.18 & OII & 48 & 8 & OIS & 018 & ofl & 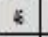 & $n$ & 8 & $\mathrm{II:2}$ & 13 & 0 & 09 & DIS: & 49 \\
\hline 8061 & oy & 108 & 118 & 10 & w & 15 & 13 & 7 & 0,1 & 02 & 25 & 0 & 301 & 10 & 008 & 0.16 & $0 \mathrm{~B}$ & 10 & v & 05 & 016 & 01 & $z$ & 11 & $\Xi$ & :184 & 13 & 0 & 29 & 2006 & I \\
\hline : $006:$ & 0.8 & $\$ 1$ & 636 & 12 & 0 & 15 & 26 & 13 & 0.88 & 11 & 1 & 0 & 128 & 8 & 0 & 005 & $0 \Omega$ & 15 & 8 & 0 & 007 & 018 & E & 12 & $\ddot{z}$ & 119 & os. & 0 & 1 & 785 & $\$ 1$ \\
\hline : $0: 6$ & 111 & 487 & 35 & 32. & 38 & 98 & 1 & $: 00$ & 402 & 2.7 & $\$ 4$ & 0 & 588 & It & 0004 & \begin{tabular}{|l|l}
18 \\
\end{tabular} & or. & 47 & 7 & 004 & 0.18 & O. & 8 & 16 & 165 & IB:4 & 13 & 0 & 44 & $3: 54$ & II \\
\hline :00:14 & 00 & 108 & $m$ & 167 & 0 & 105 & 86 & siv & 118 & 13 & 17 & 0 & 105 & 10 & 400 & 0.44 & 011 & 4 & I & 40 & 0.14 & OII & 4 & 57 & 18 & in: & 11 & 0 & 16 & [4] & x: \\
\hline :an:17 & $0 I$ & $15:$ I & 1281 & 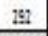 & 38 & 58 & 89 & 191 & 48 & 16 & 164 & 0 & 158 & 49 & 006 & 008 & Or & 61 & $\varepsilon$ & 0.5 & 008 & 0.8 & El & 36 & 341 & J0.4 & 15 & 0 & 46 & E:15 & 69 \\
\hline$\Delta-162$ & OIX & 935 & 134 & III & 0 & 11 & 19 & 166 & 107 & 13 & 08 & 요 & 48 & 15 & $00:$ & 018 & $0 E$ & 13 & $\Xi$ & CIE & 018 & $O E$ & 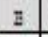 & 18 & $\Xi$ & :3: & 13 & 0 & 11 & 4.8 & 11: \\
\hline ter-0inst & $0:$ & 748 & $16 a$ & 115 & 0 & 4 & 116 & $\pi 1$ & $w_{5}$ & 12 & :11 & 0 & 31 & n & 000 & 0.12 & 0. & 40 & 101 & 0,5 & 0.12 & $\mathrm{OB}$ & 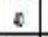 & $n$ & $7 \mathrm{n}$ & 64 & 18 & 4 & 16 & Ti:4.4 & $\underline{m s}$ \\
\hline 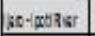 & 0.3 & $15 !$ & H. & 454 & 0 & 45 & 18 & IIII & 138 & 14 & 1.4. & 0 & 18 & 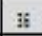 & 06 & 1198 & 18 & 17 & 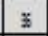 & 0.6 & 119 & 10 & I & II & 143 & 151 & In & 150 & 11 & 367 & 121 \\
\hline benan & 0.5 & 311 & 416 & 112 & $: 0$ & 11 & 62 & 331 & 18 & o. & 14 & 0 & na & $\pi$ & 0 & 0.07 & 0. & 38 & 177 & 0 & 000 & 0.5 & $\underline{I}$ & 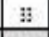 & $1: 1: 6$ & 1193 & 11 & 1 & $\vdots$ & $20: 2$ & 1002 \\
\hline ckits & 0.2 & $10 \mathrm{E}$ & 200 & 16 & 0 & gs & $\$ 9$ & 165 & 17 & $0:$ & 11 & 0 & 46 & in & 000 & 007 & $0: 1$ & $: 4$ & 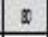 & 00 & 000 & 08 & ** & $\pi$ & 309 & 394 & 17 & 1 & 14 & $58 \pi$ & at \\
\hline (jektis & 0 & 366 & m & 111 & 0 & 14 & $\pi$ & $\mathrm{m}$ & 116 & 03 & $3:$ & 0 & 111 & 16 & 0 & 400 & OII & 10 & E & 0 & 400 & OII & y & 50 & 100 & 451 & 05 & 0 & 21 & $\pi 2$ & 78 \\
\hline 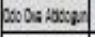 & 13 & $30 \mathrm{n}$ & 348 & TII & II & H: & 181 & $57 \%$ & \$9 & 1 & 10 & 0 & 50 & 34 & 006 & 000 & $0 \pi$ & 15 & * & 0,5 & 000 & $0:$ & 166 & II & 67 & "119 & : 16 & $\vdots$ & 91 & IIUT & $\$ 1$ \\
\hline orahat & 191 & 205 & 313 & 50 & 46 & 116 & 416 & 16: & 96 & $\$ 4$ & 85 & 0 & :11 & $\$ 4$ & 000 & 0.4 & OII & $\pi 8$ & s & 00 & (a.4 & $0: 1$ & 8 & $\Leftrightarrow$ & $70:$ & IBII & 3 & 1 & 18 & 2011 & $\pi 8$ \\
\hline ansis & 0 & 218 & 13 & 4 & if & 1 & 0.9 & 48 & 0.88 & 0.4 & 18 & 0 & II & 11 & 0 & 54 & $O u$ & 1 & I & 0 & 614 & $O A$ & 1 & $!$ & 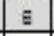 & ENS & n & 0 & 07 & 851 & 64 \\
\hline 2and? & $0 x$ & 139 & 17 & 11 & 0 & 11 & 06 & :1 & 08 & 15 & 1 & 0 & i & 8 & 000 & 000 & $0 \Omega$ & 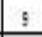 & i & 00 & 008 & QI & $\dot{s}$ & $:$ & $\pi$ & 31 & 015 & 0 & 07 & iss & i3 \\
\hline arsid4 & Oll & 934 & 976 & 316 & 0 & 16 & 15 & 121 & 065 & 05 & 12 & 0 & 93 & 15 & 008 & 006 & 0.5 & 11 & $I$ & OLE & 000 & 005 & II & 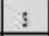 & 108 & 914 & 08 & 0 & 04 & is: & $n:$ \\
\hline asals & 0.11 & 108 & 1008 & 178 & 0 & 4 & 48 & 43 & 154 & 13 & 14 & 0 & 158 & 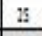 & 0 & 006 & $O E$ & 31 & $\Sigma$ & 0 & 0.08 & $0 \Omega$ & $\pi$ & 18 & $11: 6$ & $\nexists$ & 03 & 0 & $1:$ & 10.4 & $x_{1}$ \\
\hline axis? & $0: 1$ & 43 & 436 & 12 & $\therefore$ & 18 & 09 & 1118 & 108 & 1 & 13 & 0 & 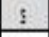 & 13 & 0 & 0.11 & 00 & 17 & E & 0 & 0.11 & 00 & II & 11 & 3) & 456 & 05 & 0 & 09 & 43 & 41 \\
\hline Dar 0 es & 08 & 204 & 411 & 61 & 0 & 13 & 1. & $\pi$ & 0.58 & 17 & 04 & 0 & 11 & 9 & 0 & 0.13 & 0.5 & 10 & 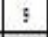 & 0 & 0.13 & $0 \mathrm{OE}$ & I & 1 & a & $13:$ & 13 & 0 & 08 & $17 \pm 1$ & 2.6 \\
\hline ilsitsi & or & 24 & 101 & 11 & 38 & 11 & 09 & 110 & 051 & os & $4:$ & 0 & 349 & u & os. & 008 & OLE & 13 & $y$ & $0 u$ & 0005 & $O B$ & B & 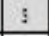 & 138 & 796 & 06 & 0 & 06 & $281:$ & III \\
\hline brasum & $0 \pi$ & 124 & 384 & 101 & 34 & 16 & 13 & $24 !$ & $0 \mathrm{n}$ & 0.4 & 4 & 0 & 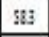 & 78 & 006 & OS. & 00 & 14 & $\Sigma$ & 00 & 0.4 & 02 & $y$ & 11 & 157 & Ins & 1 & 0 & 14 & 3266 & 1166 \\
\hline 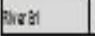 & 09 & 146 & 32 & 12 & 0 & ut & 178 & $10 \pi$ & $2 M$ & 2 & 18 & 0 & 10 & iz & OOA & 01 & OB & 4I & II & $0 a$ & 01 & $O B$ & 4 & is & m1 & 501 & 18 & 0 & 41 & 2413 & 01 \\
\hline
\end{tabular}

\section{Trace element geochemistry of stream sediments}

The trace elements analyzed in the stream sediments is presented in Table 2. The result revealed that $\mathrm{Cu}, \mathrm{Zn}, \mathrm{Ni}, \mathrm{Mn}$, $\mathrm{Th}, \mathrm{Zr}, \mathrm{Ce}$ and $\mathrm{Rb}$ have moderate to high concentrations in the sediments. $\mathrm{Cu}$ has high concentration in Odo-Owa Abidogun River and low concentration in Effon-Okemesi, Pb has high concentration in Baba orioke 8c and low concentration in Effon- Okemesi 3c, Zn has high concentration in Ede-2 and low concentration in Ilokun 1, Mn has high concentration in Baba Iyabo and low in Esa Oke 2. Thorium is high in Esa oke 17 and low in Ijero ipoti river, $\mathrm{Zr}$ is also high in Esa oke 17 and low in Okemesi 3, Ce \& Rb is high in Agbagbara and Ede respectively and low in Effon- Okemesi 2. The concentration of these trace elements in sediments is influenced by the underlying lithologic units.Ni $-\mathrm{Co}-\mathrm{Pb}$ has close values and is mostly concentrated in biotite of intermediate and acid rocks (Beus and Grigorian, 1977). As a result of weathering, these elements are released and pass directly through underground water into streams as sediments. Elements such as V, Y, Ni and La all have moderate values in the study area, the concentration cut across most of the rock types found in the area). $\mathrm{Cu}$ and $\mathrm{Ce}$ have been found to have fair concentration in the study area.Mn occurs in significant amounts in the areas especially Ikange, and other areas which quartzite is the lithologic unit. $\mathrm{Cr} / \mathrm{As}$ have values rather low for it to have been an indicator element for gold mineralization in the area. Ijero-Ipoti River has high volume of sediments which are formed as a result of weathering of the surrounding rocks and simultaneous transportation of these sediments into the nearest river. These sediments which are made up of various elements are useful for provenance characterization because they are least soluble and are relatively immobile. These elements are believed to be transported in the terrigeneous component of sediment, therefore, reflect the chemistry of their source. $\mathrm{W}, \mathrm{Be}, \mathrm{U}, \mathrm{Li}, \mathrm{Rb}, \mathrm{Ta}, \mathrm{Nb}, \mathrm{Cs}$ and Ga have distinctly high values in Ijero-IpotiRiver which is attributed to the lithologies such as pegmatite and lepidolite serving as the influencing factor. Th is also found in sediments around the area, which indicates the presence of Thbearing minerals in the area. 
Table 3. Rare earth elements in stream sediments

\begin{tabular}{|c|c|c|c|c|c|c|c|c|c|c|c|c|c|c|c|c|c|c|}
\hline Sample & Pr & Nd & $\mathrm{Sm}$ & Eu & Gd & $\mathbf{T b}$ & Dy & Ho & Er & $\mathbf{T m}$ & $\mathbf{Y b}$ & Lu & Hf & $\mathbf{L i}$ & $\mathbf{T a}$ & $\mathbf{N b}$ & Cs & $\mathbf{G a}$ \\
\hline Agbagbara & 22.1 & 79.1 & 15.2 & 1.8 & 11 & 1.3 & 5.3 & 0.6 & 1.3 & 0.2 & 1.1 & 0.1 & 1.93 & 13.1 & 4.6 & 45.53 & 1.4 & 5.96 \\
\hline baba Iyabo & 9.9 & 36.7 & 6 & 0.9 & 4.1 & 0.6 & 2.5 & 0.4 & 1 & 0.2 & 1.1 & 0.2 & 4.09 & 3 & 1.5 & 25.91 & 0.7 & 4.09 \\
\hline $\begin{array}{l}\text { Baba } \\
\text { Orioke 8b }\end{array}$ & 17.3 & 57 & 9.9 & 0.9 & 5.8 & 0.9 & 3.6 & 0.5 & 1.1 & 0.1 & 1 & 0.1 & 4.31 & 6.8 & 3.8 & 24.94 & 2.2 & 11.4 \\
\hline $\begin{array}{l}\text { Baba } \\
\text { Orioke 8c }\end{array}$ & 9.9 & 32.3 & 5.8 & 0.9 & 3.7 & 0.6 & 2.6 & 0.5 & 1.3 & 0.2 & 1.2 & 0.2 & 5.56 & 12.2 & 22.5 & 110.2 & 2.8 & 15.07 \\
\hline Ede 1 & 24 & 82.1 & 17 & 2.1 & 12 & 1.7 & 7.8 & 1.3 & 3.1 & 0.5 & 2.7 & 0.5 & 4.43 & 43.5 & 2.2 & 41.9 & 8.2 & 27.18 \\
\hline Ede 2 & 25.1 & 92.1 & 16.1 & 1.9 & 11 & 1.8 & 7.1 & 1.2 & 2.7 & 0.4 & 2.6 & 0.4 & 4.75 & 22.9 & 2 & 34 & 4.6 & 21.16 \\
\hline Effon 1 & 15.2 & 56.4 & 9.2 & 1.7 & 6.2 & 0.9 & 3.8 & 0.5 & 1.1 & 0.1 & 0.7 & 0 & 1.37 & 4.9 & 0.5 & 8.58 & 0.9 & 6.67 \\
\hline $\begin{array}{l}\text { Effon } \\
\text { Okemesi } \\
\text { 3C } \\
\end{array}$ & 4.4 & 17.1 & 2.9 & 0.7 & 2 & 0.3 & 1.5 & 0.3 & 0.5 & 0 & 0.5 & 0.1 & 1.54 & 2.7 & 0.5 & 9.03 & 0.7 & 3.42 \\
\hline $\begin{array}{l}\text { Effon } \\
\text { Okemesi }\end{array}$ & 30.1 & 102.4 & 17.6 & 2.7 & 11 & 1.6 & 5.4 & 0.8 & 1.6 & 0 & 0.9 & 0.1 & 3.56 & 1.1 & 1 & 15.67 & 0.2 & 2.08 \\
\hline $\begin{array}{l}\text { Effon } \\
\text { Okemesi } 2\end{array}$ & 19.5 & 70.7 & 11.5 & 1.9 & 7.8 & 1.1 & 4.5 & 0.5 & 1.1 & 0.2 & 0.8 & 0.1 & 3.55 & 0.7 & 0.4 & 9.69 & 0.1 & 1.76 \\
\hline Esa Oke 2 & 13.7 & 47.5 & 8.4 & 1 & 5.1 & 0.8 & 3.1 & 0.4 & 0.7 & 0.1 & 0.6 & 0 & 1.8 & 2.9 & 0.4 & 5.58 & 0.5 & 5.03 \\
\hline Esa Oke 3 & 8.1 & 29.4 & 5 & 0.6 & 3.4 & 0.6 & 2.2 & 0.3 & 0.7 & 0 & 0.3 & 0 & 0.99 & 3.6 & 0.3 & 5.19 & 0.4 & 1.78 \\
\hline Esa Oke 6 & 35.3 & 121.1 & 20.2 & 2.9 & 14 & 2 & 8.8 & 1.5 & 2.9 & 0.4 & 2.4 & 0.4 & 4.58 & 7.6 & 2 & 20.71 & 1.6 & 11.01 \\
\hline $\begin{array}{l}\text { Esa Oke } \\
14\end{array}$ & 6.7 & 25.5 & 4.1 & 0.7 & 3 & 0.5 & 1.6 & 0.3 & 0.6 & 0 & 0.5 & 0.1 & 2.65 & 2.1 & 0.2 & 9.05 & 0.7 & 3.48 \\
\hline $\begin{array}{l}\text { Esa Oke } \\
17\end{array}$ & 91.3 & 312.5 & 53.7 & 3.6 & 32 & 4.3 & 16.3 & 2 & 4 & 0.6 & 3 & 0.4 & 9.12 & 3.2 & 1.8 & 39.47 & 0.6 & 5.21 \\
\hline Ido - Ile 2 & 4.4 & 15.7 & 2.8 & 0.5 & 1.8 & 0.3 & 1.5 & 0.3 & 0.5 & 0 & 0.5 & 0 & 0.98 & 3.5 & 1.1 & 10.6 & 0.9 & 4.18 \\
\hline $\begin{array}{l}\text { Ikoro - } \\
\text { Okemesi }\end{array}$ & 19.6 & 64.8 & 10.4 & 1.2 & 6.3 & 0.7 & 2.9 & 0.4 & 0.8 & 0.1 & 0.9 & 0.2 & 2.27 & 11.6 & 3 & 26.29 & 1.9 & 6.2 \\
\hline $\begin{array}{l}\text { Ijero - } \\
\text { Ipoti River }\end{array}$ & 6.3 & 21.2 & 4.5 & 0.4 & 3.5 & 0.6 & 2.4 & 0.2 & 0.5 & 0 & 0.6 & 0 & 10.93 & 513.4 & 952 & 0 & 44.5 & 33.66 \\
\hline Ilokun 1 & 23.4 & 72.3 & 11.5 & 1.6 & 6.2 & 1.1 & 4.9 & 0.8 & 1.8 & 0.2 & 1.4 & 0.2 & 3.8 & 5.8 & 1.4 & 17.25 & 1.3 & 9.38 \\
\hline Iroko 16 & 6.2 & 21.2 & 3.4 & 0.6 & 2.4 & 0.4 & 1.2 & 0.2 & 0.5 & 0 & 0.4 & 0 & 0.97 & 14.4 & 0.6 & 7.7 & 2.4 & 8.19 \\
\hline Kajola 16 & 8.9 & 30 & 5.7 & 0.8 & 3.3 & 0.5 & 2.3 & 0.3 & 0.6 & 0.1 & 0.9 & 0.1 & 1.59 & 1.9 & 0 & 0.95 & 0.4 & 2.18 \\
\hline $\begin{array}{l}\text { Odo Owa } \\
\text { Abidogun }\end{array}$ & 42 & 144 & 25.9 & 3.8 & 16 & 2.3 & 9.2 & 1.3 & 2.2 & 0.3 & 1.5 & 0.2 & 1.48 & 51.6 & 4.7 & 34.15 & 5.1 & 21.06 \\
\hline $\begin{array}{l}\text { Ofale } \\
\text { Road }\end{array}$ & 18.4 & 65.8 & 9.5 & 1.7 & 5.9 & 1.1 & 5.1 & 1 & 2.3 & 0.3 & 2 & 0.4 & 4.02 & 10.2 & 2 & 25.48 & 2.1 & 15.07 \\
\hline Okemesi 2 & 9.4 & 32.6 & 5.6 & 0.9 & 3.2 & 0.5 & 1.8 & 0.3 & 0.5 & 0 & 0.6 & 0 & 3.78 & 1 & 0.2 & 7.6 & 0.2 & 1.05 \\
\hline Okemesi 3 & 4.8 & 14.4 & 2.9 & 0.5 & 1.4 & 0.3 & 1.1 & 0.2 & 0.2 & 0 & 0.2 & 0 & 0.82 & 1.6 & 0.1 & 2.04 & 0.3 & 1.4 \\
\hline Okemesi 4 & 4.6 & 16 & 3.1 & 0.6 & 1.6 & 0.3 & 1.1 & 0.1 & 0.4 & 0 & 0.3 & 0 & 2.95 & 1.3 & 0.1 & 4.8 & 0.3 & 1.06 \\
\hline Okemesi 6 & 11.4 & 38 & 6.3 & 0.8 & 4.5 & 0.6 & 2.9 & 0.4 & 0.7 & 0 & 0.6 & 0.1 & 2.27 & 3.2 & 0.4 & 10.7 & 0.6 & 2.91 \\
\hline Okemesi 9 & 5.2 & 17.2 & 2.9 & 0.5 & 1.9 & 0.3 & 1 & 0.2 & 0.3 & 0 & 0.2 & 0 & 1.34 & 0.8 & 0.1 & 2.99 & 0.2 & 1.42 \\
\hline Omi Osa & 1.7 & 6.3 & 1 & 0.1 & 0.9 & 0.1 & 0.6 & 0 & 0 & 0 & 0 & 0 & 0.48 & 3 & $<0.1$ & 1.89 & 0.4 & 3.01 \\
\hline $\begin{array}{l}\text { River } \\
\text { Akola }\end{array}$ & 31.9 & 111.1 & 18.1 & 3.3 & 12 & 1.8 & 6.4 & 0.9 & 1.3 & 0.2 & 0.8 & 0.1 & 2.2 & 1 & 0.2 & 5.01 & 0.3 & 1.58 \\
\hline $\begin{array}{l}\text { River } \\
\text { Elewu }\end{array}$ & 45.3 & 150.3 & 32.4 & 0.8 & 20 & 3.1 & 9.4 & 1.2 & 1.8 & 0.3 & 1.5 & 0.2 & 4.45 & 4.3 & 1.2 & 16.36 & 0.9 & 7.55 \\
\hline River Eri & 9.2 & 31.6 & 6.2 & 0.8 & 3.6 & 0.7 & 2.5 & 0.4 & 0.8 & 0.1 & 0.8 & 0.1 & 1.54 & 10.6 & 1 & 14.2 & 2.3 & 8.23 \\
\hline $\begin{array}{l}\text { River Isa } \\
7 \mathrm{C}\end{array}$ & 5.9 & 18.9 & 3.9 & 0.5 & 2.4 & 0.5 & 1.8 & 0.2 & 0.8 & 0 & 0.7 & 0 & 1.49 & 4.5 & 0.3 & 6.3 & 1.6 & 9.77 \\
\hline River Oyi & 24.3 & 82 & 14.5 & 1.3 & 8.9 & 1.2 & 4 & 0.6 & 1 & 0.1 & 0.6 & 0.1 & 1.65 & 5 & 1.6 & 13.56 & 0.9 & 3.61 \\
\hline Oke - Ila 1 & 14.2 & 46.9 & 9.4 & 0.8 & 6.4 & 0.9 & 3 & 0.4 & 0.8 & 0 & 0.6 & 0 & 1.26 & 6.2 & 0.8 & 9.46 & 0.9 & 5.82 \\
\hline
\end{tabular}

\section{Rare earth elements in Stream sediments}

The rare earth elements analyzed in the stream sediments is presented in Table 3. The elements that have conspicuous values and are anomalous concentration in the table are $\mathrm{Nd}, \mathrm{Hf}, \mathrm{Nb}$ and $\mathrm{Ga}$. The concentration and distribution of these elements is a function of the bedrock hosting them especially in the pegmatites and granites. Some of these elements are progenitors in the fractionating processes in igneous and other subsidiary rocks.

\section{Factor Analysis}

Factor analysis provided the basis for elemental associations in stream sediments. Elements are grouped into those that resulted in the mineralization of their host rocks, those that serves as pathfinder elements and those that occur as dispersed elements into their surroundings due to weathering of the host rock and transportation from source. The results of factor analysis of the stream sediments are presented in Tables 4. 
Factor Analysis of trace elements in stream sediments

Thirty-five stream sediment samples were also statistically evaluated using factor analysis. Six Component groups were derived from the analysis (Table 4).

FactorI. shows Ni-Cu-Sc-Zn-Al-Rb-Co-Mo-Fe element associations with $44.04 \%$ variance of the total. However, $\mathrm{Cu}$ and $\mathrm{Ni}$ have the highest value of 0.91 from the table, indicating $\mathrm{Cu}-\mathrm{Ni}$ mineralization in the area. $\mathrm{The} \mathrm{Cu}-\mathrm{Ni}$ mineralization is very high in Odo-Owa Abidogun River. The sources of this mineralization could also be from weathered minerals from migmatite-gneiss, quartzites, granites from within and pegmatites from Ijero area which may have been transported into the river as placer deposits. Factor II shows La-Ce-Th-Y-Zr element associations with $16 \%$ variance of the total. These element associations serve as pathfinder elements for $\mathrm{Cu}$ and $\mathrm{Ni}$ mineralization in the area while factors III, IV,V and $\mathrm{Vi}$ indicate bedrock elements which might have been dispersed into the streams during the process of weathering and sedimentation. They are $\mathrm{Ba}, \mathrm{Sr}, \mathrm{Pb}, \mathrm{K}, \mathrm{Zn}, \mathrm{Co}, \mathrm{P}, \mathrm{Mn}, \mathrm{Al}, \mathrm{U}$ and $\mathrm{Na}$. Factors $\mathrm{V}$ and $\mathrm{VI}$ is a reflection of the bedrock which are the biotite-gneiss and pegmatites.

Table 4: Factor Analysis Result of major and trace elements in stream sediments

\begin{tabular}{|c|c|c|c|c|c|c|c|}
\hline Variables & $\begin{array}{c}\text { Comp. } \\
\text { I }\end{array}$ & $\begin{array}{c}\text { Comp. } \\
\text { II }\end{array}$ & $\begin{array}{c}\text { Comp. } \\
\text { III }\end{array}$ & $\begin{array}{c}\text { Comp. } \\
\text { IV }\end{array}$ & $\begin{array}{c}\text { Comp. } \\
\text { V }\end{array}$ & $\begin{array}{c}\text { Comp. } \\
\text { VI }\end{array}$ & Communalities \\
\hline $\mathrm{Ni}$ & 0.91 & & & & & & 0.94 \\
\hline $\mathrm{Cu}$ & 0.91 & & & & & & 0.92 \\
\hline $\mathrm{Sc}$ & 0.87 & & & & & & 0.93 \\
\hline $\mathrm{V}$ & 0.82 & & & & & & 0.94 \\
\hline $\mathrm{Zn}$ & 0.77 & & & 0.43 & & & 0.89 \\
\hline $\mathrm{Al}$ & 0.58 & & 0.47 & & 0.53 & & 0.99 \\
\hline $\mathrm{La}$ & & 0.98 & & & & & 0.98 \\
\hline $\mathrm{Ce}$ & & 0.97 & & & & & 0.98 \\
\hline $\mathrm{Th}$ & & 0.89 & & & & & 0.95 \\
\hline $\mathrm{Y}$ & & 0.88 & & & & & 0.96 \\
\hline $\mathrm{Zr}$ & & 0.73 & & & & & 0.80 \\
\hline $\mathrm{Ba}$ & & & 0.98 & & & & 0.97 \\
\hline $\mathrm{Sr}$ & & & 0.96 & & & & 0.95 \\
\hline $\mathrm{Pb}$ & & & 0.91 & & & & 0.99 \\
\hline $\mathrm{K}$ & & & 0.83 & & & & 0.85 \\
\hline $\mathrm{Rb}$ & 0.46 & & 0.61 & & 0.42 & & 0.88 \\
\hline $\mathrm{Co}$ & 0.48 & & & 0.84 & & & 0.97 \\
\hline $\mathrm{P}$ & & & & 0.79 & & & 0.88 \\
\hline $\mathrm{Mo}$ & 0.50 & & & 0.76 & & & 0.89 \\
\hline $\mathrm{Fe}$ & 0.52 & & & 0.71 & & & 0.95 \\
\hline $\mathrm{Mn}$ & & & & 0.61 & & 0.50 & 0.88 \\
\hline $\mathrm{U}$ & & & & & 0.97 & & 0.95 \\
\hline $\mathrm{Na}$ & & & & & 0.95 & & 0.98 \\
\hline $\mathrm{Cr}$ & 0.63 & & & & & 0.69 & 0.91 \\
\hline $\mathrm{Ti}$ & & 0.66 & & & & 0.68 & 0.92 \\
\hline $\mathrm{EV}$ & 11.01 & 4.00 & 3.54 & 2.38 & 1.33 & 1.00 & \\
\hline $\mathrm{VAR}(\%)$ & 44.04 & 16.00 & 14.15 & 9.50 & 5.33 & 4.02 & \\
\hline $\mathrm{CVAR}$ & & & & & & & \\
\hline$(\%)$ & 44.04 & 60.04 & 74.19 & 83.69 & 89.01 & 93.03 & \\
\hline & & & & & & & \\
\hline
\end{tabular}

COMP $=$ Components (group of element associations)

VAR = Variance

CVAR= Covariance

$\%=$ Percentage 


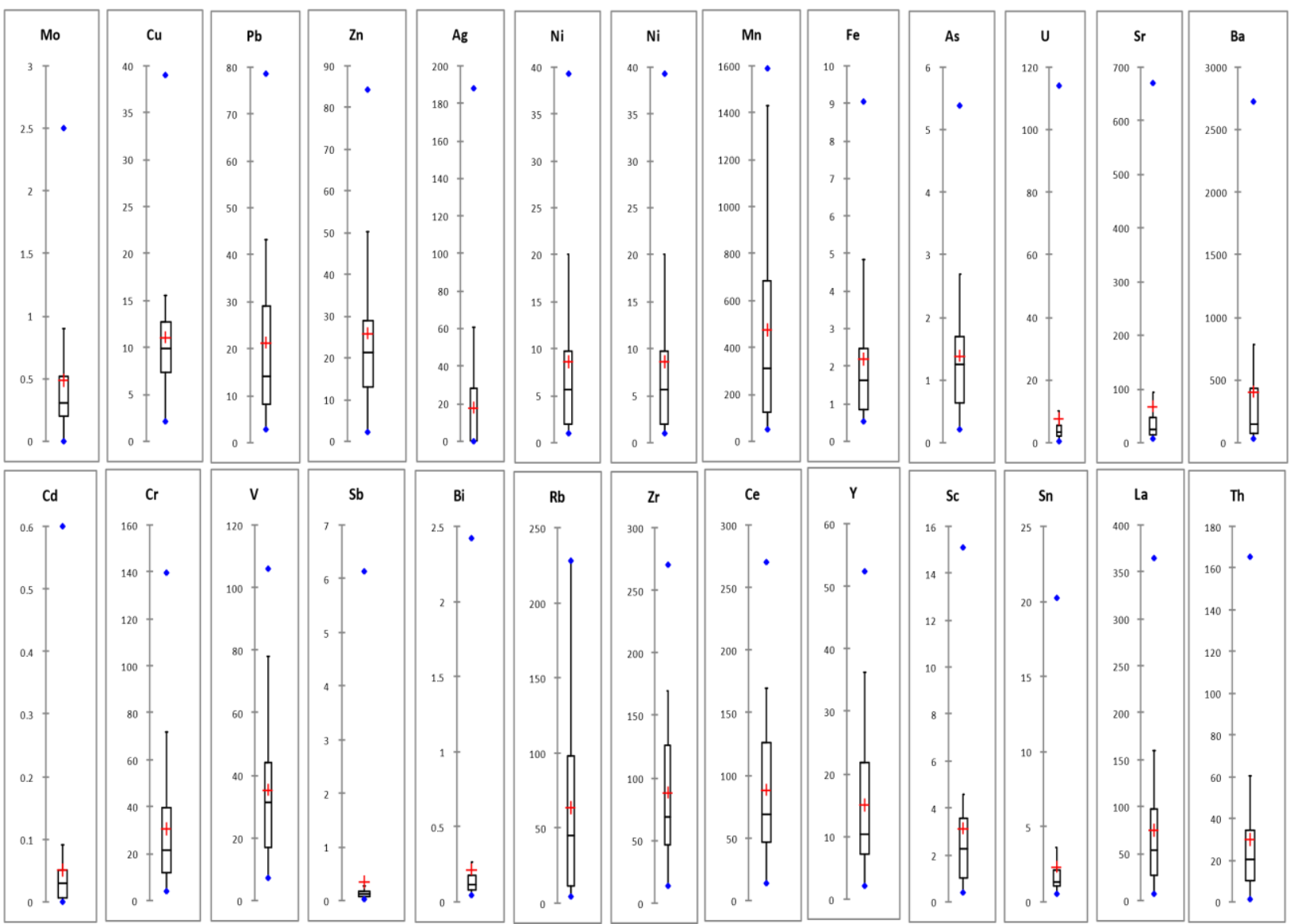

Fig. 4: Box and whisker plots showing element distribution in the analysed stream sediments. The middle line corresponds to the background value (median); lower and upper bounds of the box indicate 25th and 75th percentiles respectively. Values above the $75^{\text {th }}$ percentile are considered. Element contents between the 50 th and 75th percentiles are regarded as the threshold. (Turkey, 1977).

Table 5: Estimated background-anomalous values of the various heavy metals $(\mathrm{Mg} / \mathrm{kg})$ in the analysed stream sediments.

\begin{tabular}{|c|c|c|c|c|c|c|c|c|c|}
\hline Element & Background & Threshold & Anomaly & Contrast & Element & Background & Threshold & Anomaly & Contrast \\
\hline $\mathrm{Mo}$ & 0.48 & 0.95 & 2.51 & 5.23 & $\mathrm{Cr}$ & 30.35 & 72 & 140 & 4.61 \\
\hline $\mathrm{Cu}$ & 12.72 & 15.61 & 39.12 & 3.08 & $\mathrm{~V}$ & 35.35 & 78 & 106 & 3.00 \\
\hline $\mathrm{Pb}$ & 21.33 & 43.42 & 78.8 & 3.69 & $\mathrm{Sb}$ & 0.33 & 0.33 & 6.14 & 18.61 \\
\hline $\mathrm{Zn}$ & 25.77 & 50.4 & 84.4 & 3.28 & $\mathrm{Bi}$ & 0.22 & 0.22 & 2.42 & 11.00 \\
\hline $\mathrm{Ag}$ & 17.64 & 61 & 188 & 10.66 & $\mathrm{Rb}$ & 63.44 & 98.4 & 228.4 & 3.60 \\
\hline $\mathrm{Ni}$ & 8.55 & 20.1 & 39.3 & 4.60 & $\mathrm{Zr}$ & 88.46 & 170.2 & 270.4 & 3.06 \\
\hline $\mathrm{Mn}$ & 473.41 & 1433 & 1591 & 3.36 & $\mathrm{Ce}$ & 88.46 & 170.2 & 270.4 & 3.06 \\
\hline $\mathrm{Fe}$ & 2.18 & 4.83 & 9.05 & 4.15 & $\mathrm{Y}$ & 14.95 & 36.3 & 52.4 & 3.51 \\
\hline $\mathrm{As}$ & 1.38 & 2.7 & 5.4 & 3.91 & $\mathrm{Sc}$ & 2.31 & 3.6 & 20.3 & 8.79 \\
\hline $\mathrm{U}$ & 7.43 & 94 & 672 & 90.44 & $\mathrm{Sn}$ & 2.31 & 3.6 & 20.3 & 8.79 \\
\hline $\mathrm{Sr}$ & 66.9 & 94 & 672 & 10.04 & $\mathrm{La}$ & 74.29 & 159.7 & 364.9 & 4.91 \\
\hline $\mathrm{Ba}$ & 403.1 & 781 & 2729 & 6.77 & $\mathrm{Th}$ & 29.62 & 60.2 & 165.6 & 5.59 \\
\hline $\mathrm{Cd}$ & 0.05 & 0.09 & 0.6 & 12.00 & & & & & \\
\hline
\end{tabular}

Box and whiskers plots (generated with XLSTAT 2015) were used to describe the distribution pattern of elements concentration ranges contained in the stream sediment. Background, threshold and anomalous values were estimated using XLSTAT 2015 software® (Fig.4 \&Table 5). Element contents above the 75th percentile and outliers in each of the box plots are regarded as anomalous values as this represent a recognizable break or flexing point in the element distribution patterns (O’ Connor and Riemann, 1993). The estimated values are presented in Table 5. 


\section{$\mathrm{Mo}, \mathrm{Cu}$ and $\mathrm{Pb}$ distribution pattern}

Molybdenum has relatively low background values in the studied areas. The anomalous value of 2.51 was obtained around Ofale road sampling location. The anomaly/background ratio of the studied areas is approximately 5.23 which suggest low background value for molybdenum in the studied areas. Copper shows a background value of approximately 12.72 . The anomalous value of 39.12 was recorded in the stream sediment collected from Odo Owa Abidogun River. This suggests a geochemical signature from underlying banded gneiss. The anomaly/background contrast of approximately 3.08 was obtained which indicate a relatively high background value. $\mathrm{Pb}$ has a background value of 21.33 in the analysed stream sediment. The anomalous value of 78.8 was obtained from stream sediment sample code-named Baba Orioke $8 \mathrm{c}$ which indicate weathering from the underlying granitic/quartzitic bedrock.

\section{Zn, Ag and Ni distribution pattern}

Zinc has a background value of 25.77 in the stream sediment samples from the study areas. The anomalous value of 84.4 was obtained in samples taken around Ede 2 underlying by massive quartzite. The anomaly/background ratio in the studied stream sediments suggests relatively high background value. The background value of silver in the stream sediment sample is 17.64 . The anomalous value of 188 was obtained from the stream sediments taken from Esa Oke 2 underlying by massive quartzite. Nickel has a background value of 8.55 in the analysed stream sediment from the studied areas. The anomalous value of 39.3 was obtained from samples taken from Odo Owa Abidogun River which is structurally controlled. The anomaly/background ratio of 4.60 was obtained which indicate low background value and possible structurally controlled Ni-Cu mineralization around Odo Owa Abidogun River.

Table 6. Correlation of trace elements in stream sediments

\begin{tabular}{|l|l|l|l|l|l|l|l|l|l|l|l|}
\hline $\begin{array}{l}\text { Control } \\
\text { Variables }\end{array}$ & $\mathbf{P b}$ & $\mathbf{Z n}$ & $\mathbf{A g}$ & $\mathbf{N i}$ & $\mathbf{C o}$ & $\mathbf{M n}$ & $\mathbf{F e}$ & $\mathbf{A s}$ & $\mathbf{C r}$ & $\mathbf{V}$ & $\mathbf{C a}$ \\
\hline $\mathbf{P b}$ & 1 & 0.184 & 0.599 & 0.241 & 0.278 & -0.084 & -0.132 & -0.17 & 0.303 & 0.44 & 0.477 \\
\hline $\mathbf{Z n}$ & 0.184 & 1 & -0.04 & 0.225 & 0.345 & 0.53 & 0.178 & -0.028 & -0.011 & 0.166 & -0.012 \\
\hline $\mathbf{A g}$ & 0.599 & -0.04 & 1 & -0.151 & -0.33 & -0.54 & -0.287 & -0.809 & -0.037 & 0.124 & -0.156 \\
\hline $\mathbf{N i}$ & 0.241 & 0.225 & -0.151 & 1 & 0.778 & 0.758 & 0.579 & 0.119 & 0.817 & 0.827 & 0.687 \\
\hline $\mathbf{C o}$ & 0.278 & 0.345 & -0.33 & 0.778 & 1 & 0.807 & 0.482 & 0.409 & 0.628 & 0.515 & 0.784 \\
\hline $\mathbf{M n}$ & -0.084 & 0.53 & -0.54 & 0.758 & 0.807 & 1 & 0.759 & 0.376 & 0.652 & 0.575 & 0.432 \\
\hline $\mathbf{F e}$ & -0.132 & 0.178 & -0.287 & 0.579 & 0.482 & 0.759 & 1 & 0.199 & 0.778 & 0.577 & 0.275 \\
\hline $\mathbf{A s}$ & -0.17 & -0.028 & -0.809 & 0.119 & 0.409 & 0.376 & 0.199 & 1 & 0.042 & -0.168 & 0.522 \\
\hline $\mathbf{C r}$ & 0.303 & -0.011 & -0.037 & 0.817 & 0.628 & 0.652 & 0.778 & 0.042 & 1 & 0.91 & 0.533 \\
\hline $\mathbf{V}$ & 0.44 & 0.166 & 0.124 & 0.827 & 0.515 & 0.575 & 0.577 & -0.168 & 0.91 & 1 & 0.406 \\
\hline $\mathbf{C a}$ & 0.477 & -0.012 & -0.156 & 0.687 & 0.784 & 0.432 & 0.275 & 0.522 & 0.533 & 0.406 & 1 \\
\hline $\mathbf{C u}$ & 0.571 & 0.346 & 0.322 & 0.693 & 0.675 & 0.532 & 0.416 & -0.327 & 0.743 & 0.801 & 0.401 \\
\hline
\end{tabular}

$\mathrm{Mn}, \mathrm{Fe}$ and As distribution pattern

Mn has a background value of 473.41 in the stream sediments samples taken from the studied areas. The anomalous value of 1591 was obtained in samples taken from Esa-Oke 17 underlain by massive quartzite. The anomaly/background ratio in the analyzed stream sediments suggests high background value. Fe has a background value of 2.18 in the stream sediments. The anomalous value is 9.05 which is obtained from the stream sediments at Ofale road underlain by granitic bedrock. The anomaly/background contrast of 4.15 was obtained which indicate low background value. As has background value of 1.38 in the sampled stream sediments. Its anomalous value of 5.4 was obtained from samples taken from Ofale Road sampling location. The anomaly/ background ratio of 3.91 suggests low background value and possible mineralization and elemental association of $\mathrm{Mn}-\mathrm{Fe}-\mathrm{As}$ in analyzed stream sediments from this location.

\section{$\mathrm{U}, \mathrm{Sr}$ and Ba distribution pattern}

Uranium has a background value of 7.43 in the analyzed stream sediment samples taken from the studied areas. The anomalous value of 672 was recorded in the samples obtained from Ijero-Ipoti River underlain by pegmatites and schistose quartzites. The anomaly/background ratio in the analyzed stream sediments suggests high background value. Sr has a background value of 66.9 and its anomalous value recorded is 672 which were obtained from Baba Ori Oke 8c sampling location. The anomalous/background contrast value of 10.04 suggests low background value. Ba has a background value of 403.1 in the stream sediments obtained from the studied areas. Its anomalous value is 2729 obtained from sampling location code-named Baba- Orioke 8C. This suggests Ba-Sr mineralization in the studied area and underlying granitic bedrock. The anomaly/background ratio of 6.77 suggests low background value.

\section{$\mathrm{Cd}, \mathrm{Cr}$ and $\mathrm{V}$ distribution pattern}

Cadmium has a background value of 0.05 in the analyzed stream sediments. The anomalous value is 0.6 which was obtained from Ijero-Ipoti River sampling location in the studied area underlain by pegmatite body. The anomaly/background ratio of 12.00 suggests high background value. Chromium has a background value of 30.35 in the stream sediment samples analyzed. Its anomalous value of 140 was obtained from Baba Iyabo sampling locations underlain by massive quartzite bedrock. The anomaly/background value of 4.61 indicated a low background value. Vanadium has a background value of 35.35. The anomalous value is 106 obtained at Odo Owa Abidogun River underlain by granite-gneiss bedrock. Its anomaly/background ratio of 3.00 suggests low background value. 


\section{$\mathrm{Sb}, \mathrm{Bi}$ and $\mathrm{Rb}$ distribution pattern}

Siberium has a background value of 0.33 in the analyzed sediments. The anomalous value of 6.14 was obtained at Okemesi 2 sampling location underlain by schistose/ massive quartzite bedrock. The anomaly/background ratio of 18.61 suggests very high background value. Bismuth has a background value of 0.22 . The anomalous value is 2.42 obtained at Ijero-Ipoti River underlain by pegmatite body and very close to a quarry site in Ijero. The anomaly/background ratio of 11.00 indicates a high background value. Rubidium has a background value of 63.44. The anomalous value of 228.4 was obtained from Ede-1 sampling location underlain by quartzites. The anomaly/background ratio of 3.60 suggests a low background value.

\section{$\mathrm{Zr}$, Ce and $\mathrm{Y}$ distribution pattern}

Zircon has a background value of 88.46. The anomalous value of 270.4 was obtained at Esa-Oke 16 sampling location underlain by massive quartzite body. The anomaly/background ratio of 3.06 suggests a low background value. Cerium has a background value of 88.46 and anomalous value of 270.4 obtained at Esa-Oke 17 sediment location underlain by massive quartzites. The anomaly/background ratio of 3.06 suggests low back ground value. Yitrium has a background value of 14.95 and anomalous value of 52.4 obtained Esa-Oke 17 sampling locations. The anomaly/background ratio of 3.51 suggests low background value.

\section{Sc, Th, Sn and La distribution pattern}

Scandium has a background value of 2.31 and anomalous value of 20.3 obtained from Ede-1 sampling location underlain by quartzite lithology. The anomaly/background ratio of 8.79 suggests low background value. Thorium also has a background value of 29.62 and anomalous value of 165.6 obtained at Esa-Oke 17 underlain by quartzite. The anomaly/background ratio of

5.59 suggests low background value. Sn has a background value of 2.31 and anomalous value of 20.3 obtained at IjeroIpoti River underlain by complex pegmatite. The anomaly/background ratio of 8.79 suggests low background value. La has a background value of 74.29 and anomalous value of 364.9 also obtained from Esa Oke 17 which is underlain by massive/schistose quartzites.

The anomaly/background ratio of 4.91 is an indication of low background value of the element.

In conclusion, the factor analysis shows the association of $\mathrm{Ni}$ and $\mathrm{Cu}$ with a cumulative variance of $68.90 \%$ which suggest the possible Ni-Cu mineralization at Odo Owa Abidogun River.

\section{Correlation}

There are positive correlations between some of the heavy metals in the sediments such as $\mathrm{Cu}$ and $\mathrm{Pb}(0.571), \mathrm{Cu}$ and $\mathrm{Ni}(0.241), \mathrm{Pb}$ and $\mathrm{Zn}(0.184)$ and $\mathrm{Mn}$ and $\mathrm{Fe}(0.87)$ Table.6. The positive correlation showed that they are likely contributing simultaneously (closely associated). Poorly correlated elements might have different geochemical factors influencing their concentrations in sediments.

\section{Conclusion}

The results of geochemical mapping of the stream sediments in the study area revealed low concentration of major oxides such as $\mathrm{FeO}, \mathrm{CaO}, \mathrm{MgO}, \mathrm{Al}_{2} \mathrm{O}_{3}, \mathrm{~K}_{2} \mathrm{O}$ and $\mathrm{TiO}_{2}$ in stream sediments which could be attributed to the fact that the area is underlain by rocks that are low in olivine, pyroxene, amphibole and other minerals that bear the elements, while the average concentration of the minor/ trace element varies. $\mathrm{Ba}, \mathrm{Cr}, \mathrm{Cu}, \mathrm{Mn}$ and $\mathrm{Zn}$ have diagnostic values with respect to other elements and their values are related to bedrock lithology and also suggest the absence of basic and ultrabasic rocks in the entire study area. $\mathrm{Cu}$ has its highest concentration around Ajindo (Aworo) where biotite-gneiss was encountered within the quartzites. The rare earth elements that have conspicuous value in the stream sediments include $\mathrm{Ce}, \mathrm{Ga}, \mathrm{La}, \mathrm{Rb}$ and $\mathrm{Y}$ which are all influenced by the underlying lithologic units. However, the high percentage of Fe and $\mathrm{Al}$ conforms to the mineralogical composition of the parent rocks as being rich in aluminosilicate minerals such as olivine and mica while the presence of calcium in the sediments could be linked to the proximity of calc-gneiss in the area. Also, among the heavy metals analyzed, the group of As-Ba-Cd-Cu-Fe-K-Mn-Pb-Sb and Zinc is related to Fe-Mn mineralization (Bamigboye and Adekeye, 2011). The combinations of $\mathrm{U}, \mathrm{Zr}, \mathrm{Pb}, \mathrm{Ba}, \mathrm{Cr}, \mathrm{Ce}, \mathrm{Ni}, \mathrm{Rb}$ and $\mathrm{Zn}$ are considerably low when compared with other elements. High concentration of manganese $(\mathrm{Mn})$ indicates the presence of manganese rich minerals such as Wad, while the distribution pattern of $\mathrm{Ce}$, La and $\mathrm{P}$ indicate possible presence of monazite. The occurrence of some major oxides in higher concentration might also indicate possible mineralization of Ilmenite (due to Fe concentration) and other minerals related to manganese and phosphorous. Combinations of $\mathrm{Zr}, \mathrm{Hf}$, Th, $\mathrm{U}$ and $\mathrm{Ce}$ are related to pegmatite intrusions found within the area. The distribution patterns of the trace lements revealed that the western part of Okemesi and north eastern part of Ijero are zones marked to host mineralization due to high concentration of elements in these locations than other areas of study which indicated that ijero area is more mineralized in radioactive minerals and base metals than Ikoro, while Okemesi is richer in precious metals and industrial minerals due to large concentration of ferruginous quartzite bodies in the area. The heavy metal distribution patterns and chemical compositions of stream sediments of Ikoro and Ijero is greatly influenced by the local geology of the area. Also in Okemesi area, the heavy metals have higher and close values around the western part of the study area which is mainly underlain by quartzites of varying composition than the eastern part. Sample locations which fell in the western part of the study area is mainly underlain by quartzites (smoky) which played a significant role as the major influencing factor. It is believed 
that the various structures mapped in the studied area such as folds, fractures, joints and veins provided the frame work/groundwork that controlled the nature and type of mineralization. The study also confirmed that the studied areas are rich in base and precious metals. Therefore, copper mineralization is confirmed in the rocks and stream sediments in the study which may combine with $\mathrm{Pb}$ to form massive sulphide deposits (Elueze, 2000).

\section{References}

[1].Affaton, P., Rahaman, M.A., Trompette, R and Sougy, J. (1991). The Dahomeyide Orogen: tectonothermal evolution and relationships with the Volta Basin. In: R.D. Dallmeyer, and J.P. Lécorché , J.P. (Eds). The West African Orogens and Circum-Atlantic Correlatives. IUGS- IGCP-UNESCO Project 233, Springer-VErlag, pp. 107-122.

[2].Akanni, C.O. (1992). Aspect of Climate in Ogun State in maps edited by onakomuye, S.O ., Oyesiku, and Jegede, F.J. Ife Journal of Science. Volume 4 (2): 5-6

[3].Akintola, A.I., Ikhane, P.R., Bankole, S.I., Adeokurolere, D.N. (2013). Petrography and Stream sediment geochemistry of Ede and its environs, southwestern Nigeria. International Research Journal of Geology and Mining . 3(6):2276-6618.

[4].Allen, J.R.L (1965). Late Quaternary environments and lithofacies. American Association of Petrology and Geology Bulletin 49: 547-600.

[5].Awosika, O.A and Akpati, B.N., (1982). Reconnaissance of heavy minerals in Nigeria river sediments near Onitsha. Anambra State, Nigeria. Nigerian Minerals and Geoscience society. $19: 110-113$.

[6].Bamgboye, O.S. and Adekeye, J.I.D. (2011). Stream sediment geochemical survey of Eruku and its environs, central Nigeria : Implications for Exploration. International Journal of Research and Reviews in Applied Sciences 7(2):160172.

[7].Beus, A.A. and Grigorian, S.V. (1977). Geochemical exploration methods for mineral

deposits. Applied Publishing Limited. USA. 31-270.

[8].Clifford, T.N., 1970. The structural framework of Africa In Clifford, T.N and Gass, I.G (eds) African magmatism and tectonics, Edinburg: Oliver \& Boyd, 1-26.

[9].Dempster A.N. (1967). (GSN). 1:250,000 Sheet 61, Akure. de Swardt, A.M.J., (1953).The geology of the country around Ilesha. Geological Survey of Nigeria, Bulletin No. 23.

[10]. Elueze, A.A. (2000). Compositional appraisal and petrotectonic significance of the Imelu banded ferruginous rock in the Ilesha schist belt, southwestern Nigeria. Journal of Mining and Geology 36(1): 9-18.

[11]. Fadipe, A.A (1988). Chemical composition of Niobium-Tantalite from granitic pegmatite and alkali granites (Egbe and Ijero mineralized region). Journal of Mining and Geology, 7: 42-47.

[12]. Hubbard, F.H., (1966). A provisional report on the geology of Sheet 262(Apomu) and parts of sheet 263(Ondo). Geological Survey of Nigeria report. No. 1341(Unpublished).

[13]. Kennedy, W.Q., (1965). The influence of basement structure on the evolution of coastal (Mesozoic and Tertiary Basin of Africa) In: Salt basins around Africa. London Institute of Petroleum. 16pp.

[14]. Jacobson, R.E.E. and Webb, J.S.(1946). The Pegmatites of Central Nigeria. Geological Surrvey of Nigeria Bulletin. $16 \mathrm{pp}$.

[15]. Matheis, G., (1987). Nigerian rare metal pegmatites and their lithologic framework.Journal of geology 22 :271-291.

[16]. Matheis, G., \& Caen-Vachette, M.,(1983). Rb-Sr isotopic study of rare metal-bearing and barren pegmatites in the Pan-African reactivation zone of Nigeria. Journal of African Earth Sciences, 1, 35-40.

[17]. Mumbfu, E.M., Nforba, M.T., Cheo, E.S. (2014). Geochemical dispersion of gold in stream sediment in Paleoproterozoic Nyong Series, Southern Cameroon. Science Research. 2(6):155-165.

[18]. Macleod W.N., (1954). The geology of Jos-Bukuru younger granite complex with particular reference to the distribution of columbite. Records of geochemical survey of Nigeria. 1-17.

[19]. Nedeco., (1961).The waters of the Niger delta- The Hague, 317p

[20]. O'Connor, P.J. and Reimann, C., 1993 Multielement regional geochemical reconnaissance as an aid to target selection in Irish Caledonian terrains. Journal of Geochemical Exploration. 47:63 -89.

[21]. Rupasinghe, D.L, Ranasighe, G.W.A.R, Fernado, C.B, Dissanayake, M.S. (2009). Statistical evaluation of stream sediment geochemistry in interpreting the river catchment of highgrade metamorphic terrains. Journal of Geochemical Exploration 103:97-114.

[22]. Turkey, J.W. 1977. "Box and whisker plots" ‘2C in Exploratory Data Analysis Reading, M A: Addison-Wesley, 39-43.

[23]. Watts, D.W., and Johnson, M.H., (2012). Geochemical mapping using stream sediments inwest-central Nigeria. Implications for environmental studies and mineral exploration in west Africa. Applied geochemistry, 27 (6): 1035 1062 . 